\title{
Increase of Organic Carbon Pool in Reclaimed Soils under Forest Stand ${ }^{4}$
}

\begin{abstract}
This paper contains the results of the studies on the content of organic carbon in the initial soils formed from soilless formations reclaimed for forest management. The obtained data allowed for the assessment of the carbon resources in the organic layer and in the mineral layers close to the surface. It also allowed us to make models that enabled us to determine the main factors influencing the rate of the increase. The strongest influence on the carbon sequestration during the forest reclamation of soilless formations has their lithology (granulation) and species composition of the planted trees. The time and situation (on a slope or a horizontal surface) are less important. The calculated annual increase of carbon indicates that the period necessary to store carbon in reclaimed soils in the quantities similar to the ones occurring in the soils of a natural forest is more than 100 years.
\end{abstract}

Keywords: reclamation, soilless areas, sequestration of C, soil carbon turnover

Received: 7 August 2017; accepted: 4 July 2019

1 AGH University of Science and Technology, Faculty of Mining Surveying and Environmental Engineering, Department of Environmental Management and Protection, Krakow, Poland, email: sgrusz@agh.edu.pl

ORCID ID: https://orcid.org/0000-0002-8811-0954

2 AGH University of Science and Technology, Faculty of Mining Surveying and Environmental Engineering, Department of Environmental Management and Protection, Krakow, Poland, email: sroka@agh.edu.pl

ORCID ID: https://orcid.org/0000-0002-4274-8872

3 AGH University of Science and Technology, Faculty of Mining Surveying and Environmental Engineering, Department of Environmental Management and Protection, Krakow, Poland, email: wojtan@agh.edu.pl

ORCID ID: https://orcid.org/0000-0001-7729-7509

${ }_{4}$ Grants to the Research Project by the Ministry of Science and Higher Education Republic of Poland No. NN 523614539 


\section{Introduction}

The management of soil organic carbon is regarded as a significant factor in the regulation of carbon dioxide balance on a global scale. The mechanism of $C$ storage in soils involves the assimilation of atmospheric carbon dioxide by plants, its transformation into organic $C$ of plant tissues, deposition in soils as litter or root exudates, and subsequent humification and retention in the soils as soil organic matter. According to recent estimations, soils constitute the largest terrestrial deposit of global carbon [1-3]. Therefore, sustainable agricultural and forest management is required to help protect the Earth's climate [4,5].

The sustainable management of the organic carbon in soils requires the knowledge on the size of the $C$ deposit in soils and on the $C$ accumulation rate. To assess the amount of $\mathrm{C}$ in soils, several models can be developed involving climatic, lithological, and typological factors as well as land use. The models assume that, at stabile climatic, lithological and typological factors, the $\mathrm{C}$ pool is generally constant (apart from seasonal changes). The change of $C$ in soils is driven mainly by the change in land use [6-8]. The most drastic form of land-use change is taking soils for industrial or economic activity. Such a change of land use may cause the persistent liquidation of ecological functions and a total devastation of the soils, transforming the land into soilless barrens. Post-industrial barrens are often reclaimed for agriculture or forestry. The reclamation for agriculture or forestry requires the initiation of a soil-forming process. Recent studies indicate that the first stages of soil formation in reclaimed soilless areas are very dynamic; the initial organic matter-enriched horizons appear after a few years [9-13].

The reclamation of soilless barrens gives us the opportunity to observe the accumulation rate of organic carbon, and the proper selection of objects allow for the assessment of the influence of lithological and morphological factors and the method of land use on this process. Collecting the proper data will allow for the improvement of the existing models and recommendations in the management of soils, guaranteeing their protection and, if possible, increasing the carbon content.

The studies were meant to define the conditions (lithological, morphological, and phytocoenotic) of the accumulation rate of organic carbon (SOC) in reclaimed soils made out of raw soilless formations as well as to assess its content.

\section{Study Objects}

The study was carried out at three post-mining areas: the dumps of the "Betchatów" lignite mine, "Turów" lignite mine, and former "Machów" sulfur mine. The mineral background of these objects before reclamation did not contain soil organic carbon. 


\section{Methods}

\subsection{Soil Sampling}

The sampling plots were chosen considering several factors, such as the textural type, composition and age of the tree stands as well as the situation in the area (slope-scarps, flat shelves, tops of the dumps). For each sampling plot, the species composition of the tree stand was recorded, and the height, forest crown cover, and diameters at breast height (DBH) of the trees were measured. The sample was taken by an increment borer to assess the ages of the trees. On each plot $(10 \times 10 \mathrm{~m})$, five points were chosen in an "envelope" system, from which the first plant litter was taken from an area of $0.25 \mathrm{~m}^{2}$. After removing the litter, samples of the intact structure were taken in metal Eijkelkamp cylinders from depths of $0-5 \mathrm{~cm}$ and $5-10 \mathrm{~cm}, 10-20 \mathrm{~cm}$ and $20-40 \mathrm{~cm}$, and (in the case of Turów) $40-55 \mathrm{~cm}$.

\subsection{Laboratory Analyses}

The soil texture of the samples was determined hydrometrically (according to PN-ISO 11277:2005). The content total nitrogen was according to Kjeldahl metod (Büchi, Kjelflex K-360). The $\mathrm{pH}$ of the samples was measured in $1 \mathrm{M} \mathrm{KCl}$ solution (soil:liquid ratio 1:5, w:v) with a digital pH-meter (Elemtron CPC-401). The bulk density based on the weight of samples of intact structure, taken in cylinders of a known volume (Kopecky's cylinders). The total carbon (TC) and inorganic carbon (IC) was determined on a CS elemental analyzer (ELTRA CS 500). The soil organic carbon (SOC) content was calculated by subtracting the content of inorganic $\mathrm{C}$ from the total $\mathrm{C}$ concentration of the material.

\subsection{Sampling Points}

Characteristics of the sampling points and the results of the field measurements are presented in Table 1.

Table 1. Characteristics of sampling plots

\begin{tabular}{|c|c|c|c|c|c|c|c|}
\hline \multicolumn{3}{|c|}{ Sampling plots } & \multirow{2}{*}{$\begin{array}{l}\text { Textural } \\
\text { category }\end{array}$} & \multirow{2}{*}{ Dominant tree } & \multirow{2}{*}{$\begin{array}{l}\text { Tree } \\
\text { age }\end{array}$} & \multirow{2}{*}{$\begin{array}{c}\text { Height } \\
{[\mathrm{m}]}\end{array}$} & \multirow{2}{*}{$\begin{array}{l}\mathrm{DBH} \\
{[\mathrm{cm}]}\end{array}$} \\
\hline No. & Situation & Exposure & & & & & \\
\hline \multicolumn{8}{|c|}{ Bełchatów } \\
\hline 1,2 & scarp & $\mathrm{N}$ & coarse & Quercus robur L. & $18-22$ & $10-14$ & $5-21$ \\
\hline 3,4 & top parts & - & medium & Larix decidua Mill. & $\sim 18$ & $10-17$ & $16-24$ \\
\hline 5,6 & foothill & $\mathrm{N}$ & coarse & Pinus sylvestris L. & $\sim 15$ & $4-11$ & $2-17$ \\
\hline 7 & top parts & - & coarse & Pinus sylvestris L. & $\sim 11$ & $4-5$ & $2-9$ \\
\hline 8,9 & top parts & - & medium & Pinus sylvestris L. & $18-20$ & $7-9$ & $6-14$ \\
\hline
\end{tabular}


Table 1. cont.

\begin{tabular}{|c|c|c|c|c|c|c|c|}
\hline \multicolumn{3}{|c|}{ Sampling plots } & \multirow{2}{*}{$\begin{array}{l}\text { Textural } \\
\text { category }\end{array}$} & \multirow{2}{*}{ Dominant tree } & \multirow{2}{*}{$\begin{array}{l}\text { Tree } \\
\text { age }\end{array}$} & \multirow{2}{*}{$\begin{array}{c}\text { Height } \\
\text { [m] }\end{array}$} & \multirow{2}{*}{$\begin{array}{l}\mathrm{DBH} \\
{[\mathrm{cm}]}\end{array}$} \\
\hline No. & Situation & Exposure & & & & & \\
\hline \multicolumn{8}{|c|}{ Machów } \\
\hline 1,2 & top parts & - & fine & Fraxinus excelsior L. & $\sim 22$ & $6-14$ & $7-20$ \\
\hline 3,4 & scarp & $\mathrm{N}-\mathrm{W}$ & fine & Alnus glutin. Gaertn & $\sim 21$ & $8-15$ & $5-17$ \\
\hline 5,6 & shelf & S-E, E & fine & $\begin{array}{l}\text { Alnus glutin. Gaertn, } \\
\text { Acer platanoides L. } \\
\text { Fraxinus excelsior L. }\end{array}$ & $\sim 18$ & $3-17$ & $3-17$ \\
\hline \multicolumn{8}{|c|}{ Turów } \\
\hline 1,2 & shelf & $\mathrm{W}$ & fine & Pinus sylvestris L. & $\sim 28$ & $12-16$ & $\sim 12$ \\
\hline 3,4 & scarp & $\mathrm{W}$ & fine & Alnus glutin. Gaertn & $\sim 30$ & $17-20$ & 14-15 \\
\hline 5,6 & scarp & $\mathrm{W}$ & fine & Larix decidua Mill. & $\sim 30$ & $19-22$ & $\sim 20$ \\
\hline 7 & scarp & $\mathrm{W}$ & fine & Betula pendula Roth. & $\sim 30$ & $17-20$ & $\sim 18$ \\
\hline
\end{tabular}

\section{Results}

The overall results are shown in Figure 1 and Table 2.

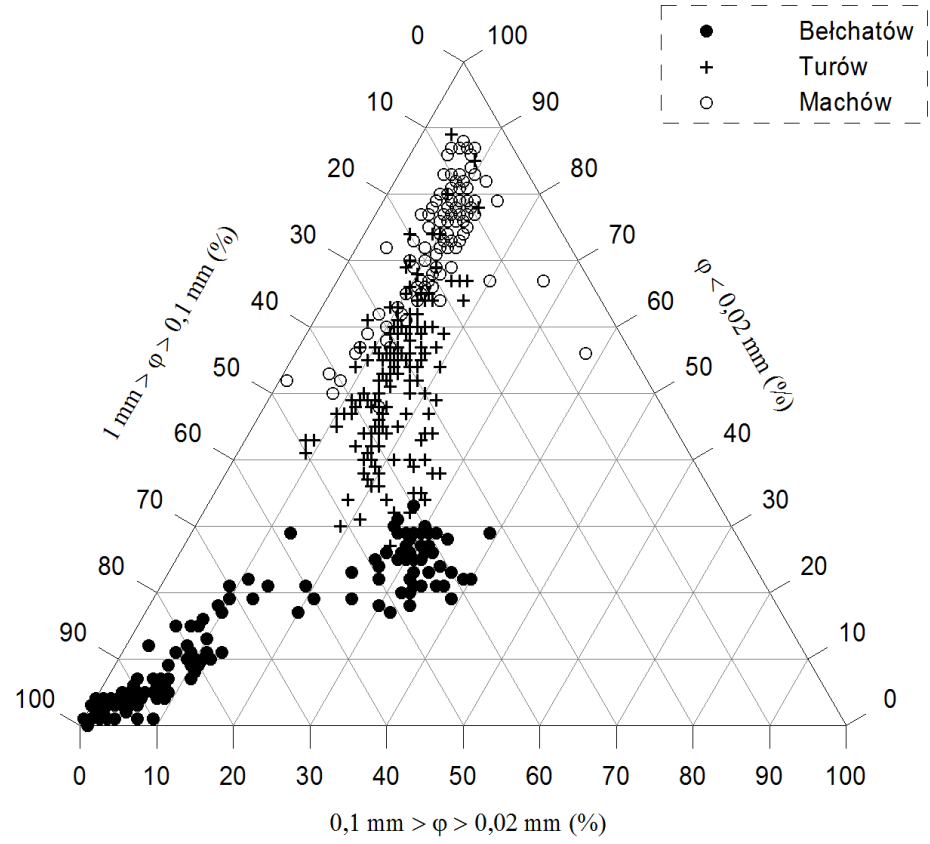

Fig. 1. Texture of samples from dumps of "Bełchatów," "Machów," and "Turów" mines 
Table 2. Overall results of studies

\begin{tabular}{|c|c|c|c|c|c|c|c|c|c|}
\hline \multirow{2}{*}{$\begin{array}{l}\text { Sampling } \\
\text { points }\end{array}$} & \multirow{2}{*}{$\begin{array}{l}\text { Number } \\
\text { of samples }\end{array}$} & \multirow{2}{*}{$\begin{array}{c}\text { Layer } \\
{[\mathrm{cm}]} \\
\end{array}$} & \multirow{2}{*}{\begin{tabular}{|c|c}
$\begin{array}{c}\text { Bulk } \\
\text { density }\end{array}$ \\
{$\left[\mathrm{g} \cdot \mathrm{cm}^{-3}\right]$}
\end{tabular}} & \multicolumn{2}{|c|}{ SOC $[\%]$} & \multicolumn{2}{|c|}{$\mathrm{N}[\%]$} & \multirow{2}{*}{$\begin{array}{c}\mathrm{pH} \\
\mathrm{KCl}\end{array}$} & \multirow{2}{*}{$\mathrm{SOC} / \mathrm{N}$} \\
\hline & & & & mean & SD & mean & SD & & \\
\hline \multicolumn{10}{|c|}{ Bełchatów } \\
\hline \multirow{5}{*}{1 and 2} & 10 & litter & $725.6^{*}$ & 38.95 & 6.34 & 1.031 & 0.266 & $4.7-5.4$ & 37.8 \\
\hline & 10 & $0-5$ & 1.26 & 1.45 & 1.05 & 0.080 & 0.054 & $4.2-7.0$ & 18.1 \\
\hline & 10 & 5-10 & 1.49 & 0.31 & 0.15 & 0.020 & 0.007 & $4.1-6.8$ & 15.5 \\
\hline & 10 & $10-20$ & $1.52^{* *}$ & 0.20 & 0.08 & 0.011 & 0.005 & $4.1-7.3$ & 18.2 \\
\hline & 10 & $20-40$ & $1.53^{* *}$ & 0.10 & 0.03 & 0.005 & 0.002 & $4.2-8.0$ & 20.0 \\
\hline \multirow{5}{*}{3 and 4} & 10 & litter & $1904.4^{*}$ & 31.64 & 3.61 & 0.841 & 0.099 & $4.9-5.6$ & 37.6 \\
\hline & 10 & $0-5$ & 1.28 & 1.72 & 0.61 & 0.085 & 0.030 & $6.0-7.6$ & 20.2 \\
\hline & 10 & 5-10 & 1.47 & 0.64 & 0.15 & 0.032 & 0.005 & $7.5-7.8$ & 20.0 \\
\hline & 10 & $10-20$ & $1.57^{* *}$ & 0.42 & 0.18 & 0.022 & 0.003 & $7.4-7.8$ & 19.1 \\
\hline & 10 & $20-40$ & $1.59^{* *}$ & 0.33 & 0.10 & 0.019 & 0.002 & $7.3-7.8$ & 17.4 \\
\hline \multirow{5}{*}{5 and 6} & 10 & litter & $740.6^{*}$ & 34.81 & 11.95 & 0.812 & 0.199 & $4.9-5.2$ & 42.9 \\
\hline & 10 & $0-5$ & 1.38 & 1.39 & 0.51 & 0.076 & 0.021 & $5.7-7.5$ & 18.3 \\
\hline & 10 & 5-10 & 1.50 & 0.94 & 0.37 & 0.050 & 0.014 & $5.6-7.8$ & 18.8 \\
\hline & 10 & $10-20$ & $1.49^{* *}$ & 0.71 & 0.25 & 0.036 & 0.010 & $5.4-7.9$ & 19.7 \\
\hline & 10 & $20-40$ & $1.54^{* *}$ & 0.47 & 0.35 & 0.026 & 0.016 & $5.0-7.9$ & 18.1 \\
\hline \multirow{5}{*}{7} & 5 & litter & $414^{*}$ & 40.83 & 6.63 & 0.639 & 0.154 & $4.5-6.5$ & 63.9 \\
\hline & 5 & $0-5$ & $1.24^{* *}$ & 2.23 & 1.89 & 0.064 & 0.049 & $7.0-7.7$ & 34.8 \\
\hline & 5 & $5-10$ & $1.29^{* *}$ & 2.22 & 2.44 & 0.040 & 0.037 & $7.5-7.9$ & 55.5 \\
\hline & 5 & $10-20$ & $1.51^{* *}$ & 0.43 & 0.50 & 0.012 & 0.011 & $7.2-8.1$ & 35.8 \\
\hline & 5 & $20-40$ & $1.54^{* *}$ & 0.14 & 0.09 & 0.007 & 0.005 & $6.7-8.1$ & 20.0 \\
\hline \multirow{5}{*}{8 and 9} & 10 & litter & $922.3^{*}$ & 36.44 & 5.74 & 0.761 & 0.189 & $4.8-7.2$ & 47.9 \\
\hline & 10 & $0-5$ & 1.40 & 1.06 & 0.37 & 0.054 & 0.020 & $5.6-7.0$ & 19.6 \\
\hline & 10 & 5-10 & 1.61 & 0.65 & 0.16 & 0.026 & 0.006 & $7.6-8.0$ & 25.0 \\
\hline & 10 & $10-20$ & $1.57^{* *}$ & 0.44 & 0.15 & 0.017 & 0.003 & $7.8-8.1$ & 25.9 \\
\hline & 10 & $20-40$ & $1.58^{* *}$ & 0.30 & 0.18 & 0.011 & 0.004 & $7.7-8.3$ & 27.3 \\
\hline \multicolumn{10}{|c|}{ Machów } \\
\hline \multirow{5}{*}{1 and 2} & 10 & litter & $726.6^{*}$ & 36.82 & 3.81 & 1.302 & 0.267 & $6.0-6.3$ & 28.3 \\
\hline & 10 & $0-5$ & 0.98 & 3.72 & 0.74 & 0.334 & 0.012 & $7.3-7.3$ & 11.1 \\
\hline & 10 & 5-10 & 1.15 & 1.63 & 0.24 & 0.136 & 0.014 & $7.4-7.5$ & 11.9 \\
\hline & 10 & $10-20$ & $1.30^{* *}$ & 1.03 & 0.20 & 0.087 & 0.011 & $7.3-7.6$ & 11.8 \\
\hline & 10 & $20-40$ & $1.08^{* *}$ & 1.05 & 0.06 & 0.079 & 0.008 & $7.2-7.6$ & 13.3 \\
\hline \multirow{2}{*}{3 and 4} & 10 & litter & $1124.1^{*}$ & 31.30 & 6.25 & 1.304 & 0.213 & $6.0-6.6$ & 24.0 \\
\hline & 10 & $0-5$ & 0.89 & 4.78 & 1.13 & 0.346 & 0.028 & $7.3-7.3$ & 13.8 \\
\hline
\end{tabular}


Table 2. cont.

\begin{tabular}{|c|c|c|c|c|c|c|c|c|c|}
\hline \multirow{2}{*}{$\begin{array}{c}\text { Sampling } \\
\text { points }\end{array}$} & \multirow{2}{*}{$\begin{array}{l}\text { Number } \\
\text { of samples }\end{array}$} & \multirow{2}{*}{$\begin{array}{c}\text { Layer } \\
{[\mathrm{cm}]}\end{array}$} & \multirow{2}{*}{$\begin{array}{c}\text { Bulk } \\
\text { density }\end{array}$} & \multicolumn{2}{|c|}{ SOC [\%] } & \multicolumn{2}{|c|}{$\mathrm{N}[\%]$} & \multirow{2}{*}{$\begin{array}{c}\mathrm{pH} \\
\mathrm{KCl}\end{array}$} & \multirow{2}{*}{$\mathrm{SOC} / \mathrm{N}$} \\
\hline & & & & mean & SD & mean & SD & & \\
\hline & 10 & 5-10 & 1.18 & 1.67 & 0.50 & 0.139 & 0.024 & $7.4-7.5$ & 12.0 \\
\hline & 10 & $10-20$ & $1.31^{* *}$ & 1.08 & 0.18 & 0.082 & 0.014 & $7.4-7.7$ & 13.2 \\
\hline & 10 & $20-40$ & $1.26^{* *}$ & 1.01 & 0.17 & 0.078 & 0.008 & $7.3-7.6$ & 12.9 \\
\hline \multirow{5}{*}{5 and 6} & 10 & litter & $960.2^{*}$ & 32.97 & 6.67 & 1.313 & 0.250 & $6.0-6.7$ & 25.4 \\
\hline & 10 & $0-5$ & 0.95 & 4.64 & 0.70 & 0.369 & 0.028 & $7.3-7.3$ & 12.7 \\
\hline & 10 & 5-10 & 1.24 & 1.64 & 0.36 & 0.143 & 0.020 & $7.4-7.5$ & 11.5 \\
\hline & 10 & $10-20$ & $1.29^{* *}$ & 1.12 & 0.14 & 0.096 & 0.010 & $7.3-7.5$ & 11.8 \\
\hline & 10 & $20-40$ & $1.29^{* *}$ & 1.12 & 0.14 & 0.087 & 0.010 & $7.3-7.5$ & 12.9 \\
\hline \multicolumn{10}{|c|}{ Turów } \\
\hline \multirow{6}{*}{1 and 2} & 10 & litter & $3607^{*}$ & 40.05 & 3.99 & 0.950 & 0.091 & $4.1-4.4$ & 42.5 \\
\hline & 10 & $0-5$ & 0.97 & 6.76 & 1.45 & 0.156 & 0.043 & $4.0-4.7$ & 44.5 \\
\hline & 10 & 5-10 & 1.11 & 4.56 & 1.42 & 0.085 & 0.017 & $4.2-5.0$ & 53.5 \\
\hline & 10 & $10-20$ & $1.08^{* *}$ & 4.11 & 1.31 & 0.071 & 0.017 & $4.0-5.2$ & 57.0 \\
\hline & 10 & $20-40$ & $1.12^{* *}$ & 3.45 & 1.49 & 0.062 & 0.016 & $3.7-5.0$ & 54.3 \\
\hline & 9 & $40-55$ & $1.10^{* *}$ & 3.84 & 1.62 & 0.056 & 0.015 & $3.5-5.1$ & 66.4 \\
\hline \multirow{6}{*}{3 and 4} & 10 & litter & $1930.8^{*}$ & 32.79 & 6.21 & 1.112 & 0.234 & $3.9-4.9$ & 30.9 \\
\hline & 10 & $0-5$ & 0.77 & 11.72 & 3.15 & 0.477 & 0.183 & $3.8-4.3$ & 24.6 \\
\hline & 10 & 5-10 & 1.03 & 7.70 & 2.07 & 0.228 & 0.127 & $3.9-4.2$ & 37.2 \\
\hline & 10 & $10-20$ & $1.00^{* *}$ & 4.99 & 1.56 & 0.110 & 0.022 & $3.7-4.2$ & 45.8 \\
\hline & 10 & $20-40$ & $1.05^{* *}$ & 3.91 & 1.05 & 0.079 & 0.014 & $3.4-4.4$ & 49.5 \\
\hline & 8 & $40-55$ & $1.03^{* *}$ & 4.72 & 2.63 & 0.084 & 0.026 & $3.5-4.6$ & 53.7 \\
\hline \multirow{6}{*}{5 and 6} & 10 & litter & $2696^{*}$ & 35.42 & 3.71 & 1.030 & 0.140 & $4.4-4.8$ & 34.6 \\
\hline & 10 & $0-5$ & 0.92 & 9.74 & 2.79 & 0.276 & 0.083 & $4.1-4.4$ & 35.7 \\
\hline & 10 & $5-10$ & 0.98 & 6.45 & 1.94 & 0.117 & 0.018 & $3.8-4.6$ & 54.6 \\
\hline & 10 & $10-20$ & $1.02^{* *}$ & 5.34 & 1.98 & 0.095 & 0.028 & $3.9-4.7$ & 55.1 \\
\hline & 10 & $20-40$ & $1.02^{* *}$ & 4.77 & 1.96 & 0.081 & 0.019 & $3.7-4.6$ & 56.7 \\
\hline & 9 & $40-55$ & $1.00^{* *}$ & 5.38 & 1.51 & 0.088 & 0.016 & $3.8-4.2$ & 60.5 \\
\hline \multirow{6}{*}{7} & 5 & litter & $1836^{*}$ & 37.43 & 5.27 & 1.231 & 0.279 & $5.1-5.6$ & 31.1 \\
\hline & 5 & $0-5$ & 0.78 & 9.58 & 2.87 & 0.265 & 0.060 & $4.1-5.1$ & 56.3 \\
\hline & 5 & $5-10$ & 0.95 & 5.15 & 2.61 & 0.112 & 0.027 & $4.1-4.9$ & 46.0 \\
\hline & 5 & $10-20$ & $1.06^{* *}$ & 4.57 & 2.43 & 0.090 & 0.025 & $4.0-4.4$ & 48.3 \\
\hline & 5 & $20-40$ & $1.08^{* *}$ & 4.11 & 1.96 & 0.078 & 0.018 & $3.8-4.3$ & 49.5 \\
\hline & 4 & $40-55$ & $0.98^{* *}$ & 6.04 & 0.20 & 0.087 & 0.006 & $3.8-4.1$ & 69.7 \\
\hline
\end{tabular}

* litter mass $\left[\mathrm{g} \cdot \mathrm{m}^{-2}\right]$,

** modeled values. 


\section{Data Processing}

Determining the SOC pool (the mass of the organic carbon per area unit) requires knowledge of the SOC content in the soil and the bulk density of the soil.

A part of the soil (a profile from below a depth of $10 \mathrm{~cm}$ ) was sampled with the disturbance of the structure. To estimate the potential carbon stock below this depth, a model was constructed to allow for an estimation of the density in the lower layers of the soil. After tests with different models, one that was recognized as sufficiently good was obtained by the MARSpline (Multivariate Adaptive Regression Splines) algorithm [14]. This model included the total content of the organic carbon SOC [\%], the content of the fine loam fraction $0.002<\varphi<0.006 \mathrm{~mm}[\%]$, the content of the sand fraction $0.1<\varphi<1 \mathrm{~mm}[\%]$, and its determination coefficient was $R^{2}=0.77$ (average co-efficient in five-fold validation $R^{2}=0.69$ ).

According to the carried-out observations, all of the studied soil materials contained a certain initial level of organic carbon of a geological origin [15-18]. This pool should be subtracted from the present content of organic carbon, as it did not come from the current soil-forming processes.

Following the results of previous studies [9-11, 13, 19-24], it was assumed that the processes of organic matter accumulation in mine soils reclaimed for forestry does not reach deeper than $30 \mathrm{~cm}$. It was assumed that the content below this depth is an initial concentration for a given profile.

The dump materials of the "Turów" lignite mine are additionally enriched by the anthropogenic carbon coming from the power plant ash that was added to the dumped material. Its subtraction from the carbon accumulated as a result of the soil-forming processes requires a special algorithm. Having a relationship between the contents of $\mathrm{C}$ and $\mathrm{N}$ in the grounds without ash (Bełchatów and Machów), a model of neural networks was built. A module of the so-called Automated Neural Networks of the STATISTICA package was applied. A model consisted of five independently trained neural networks with the genetic selection of input features and mean content if indications as a model content. The individual networks (input: percentage of particular particle size fractions, the $\mathrm{N}$ and $\mathrm{C}$ content) were characterized by determination indexes for the validation set within a range of $R^{2}=0.92-0.94$. This model allowed for an estimation of the real increase of organic carbon in the soils from the dump in Turów.

\section{Interpretation of Results}

To assess the scale of carbon accumulation and compare it with the properties of the sites, an analysis covering the present state of the litter mass, the carbon contained in the litter, and the mineral layer of soils as well as the analysis of factors influencing the increase of the pool of organic carbon were carried out, and a perspective of the stabilization of its resources was considered [25-27]. 


\subsection{Litter}

In the case of the studied objects, both the litter mass and the content of the carbon in the litter were clearly higher in Turów than they were in Machów and Bełchatów (Tabs. 3, 4).

Table 3. Litter mass in sampled soil profiles of studied objects $\left[\mathrm{Mg} \cdot \mathrm{ha}^{-1}\right]$

\begin{tabular}{||l|c|c|c|c|c|c|c|}
\hline \hline \multicolumn{1}{|c|}{ Object } & No. & Mean & Minimum & Maximum & $\begin{array}{c}\text { Lower } \\
\text { quartile }\end{array}$ & $\begin{array}{c}\text { Upper } \\
\text { quartile }\end{array}$ & $\begin{array}{c}\text { Standard } \\
\text { deviation }\end{array}$ \\
\hline \hline Bełchatów & 45 & 10.0 & 2.4 & 35.6 & 5.0 & 12.8 & 6.6 \\
\hline Machów & 30 & 9.4 & 3.2 & 25.3 & 6.8 & 10.9 & 4.3 \\
\hline Turów & 34 & 26.7 & 10.2 & 71.2 & 17.4 & 33.3 & 12.9 \\
\hline
\end{tabular}

Table 4. Mass of carbon in litter of sampled soil profiles of studied objects $\left[\mathrm{Mg} \cdot \mathrm{ha}^{-1}\right]$

\begin{tabular}{||l|c|c|c|c|c|c|c|}
\hline \hline \multicolumn{1}{|c|}{ Object } & No. & Mean & Minimum & Maximum & $\begin{array}{c}\text { Lower } \\
\text { quartile }\end{array}$ & $\begin{array}{c}\text { Upper } \\
\text { quartile }\end{array}$ & $\begin{array}{c}\text { Standard } \\
\text { deviation }\end{array}$ \\
\hline \hline Bełchatów & 45 & 3.38 & 0.81 & 10.57 & 2.01 & 4.48 & 1.95 \\
\hline Machów & 30 & 3.02 & 1.31 & 6.34 & 2.25 & 3.43 & 1.10 \\
\hline Turów & 34 & 9.55 & 3.52 & 26.27 & 6.55 & 11.36 & 4.61 \\
\hline
\end{tabular}

This indicates differences in the conditions of the accumulation and decomposition of the organic substance. The constructed MARSpline model referring to the mass of the litter allows for the automatic selection of explaining variables (quantitative and qualitative) depending on their significance in the model. The starting set of explaining variables included the content of fraction $\varphi<0.02 \mathrm{~mm}$ in the upper layer of the soil [\%], age of the tree stand, textural category (light, medium, heavy), situation (top, scarp, shelf, foothill), species composition in the tree stand, and object (B - Bełchatów, M - Machów, T - Turów). The model obtained under these conditions takes the following form:

$$
L i t t=18.96+27.04 \times B F 1-0.72 \times B F 2-7.81 \times B F 3-4.04 \times B F 4,
$$

where:

$$
\begin{aligned}
\text { Litt } & - \text { mass of litter }\left[\mathrm{Mg} \cdot \mathrm{ha}^{-1}\right] \\
B F 1 & =1 \text { for object Turów and } 0 \text { in other cases, } \\
B F 2 & =\max (0, \text { Age }-11), \text { Age }- \text { age of stand [years] } \\
B F 3 & =1 \text { for birch stand (Betula pendula) and } 0 \text { in other cases, } \\
B F 4 & =1 \text { for alder-ash stand (Alnus glutinosa }+ \text { Fraxinus excelsior) and } 0 \text { in other cases. }
\end{aligned}
$$

The model is very approximate, as indicated by the value of the coefficient of determination $\left(R^{2}=0.56\right.$, average coefficient in five-fold validation $\left.R^{2}=0.51\right)$, among others. This indicates that the accumulation of the litter changes with age and that it is lower in the case of birch Betula and alder-ash Alnus-Fraxinus tree stands. 
Similar conclusions can be drawn from the other model approximating the estimation of the mass of carbon contained in the litter.

\subsection{Content of Organic Carbon in Soil Profile (Mineral Formations)}

The mass of the organic carbon $\left[\mathrm{Mg} \cdot \mathrm{ha}^{-1}\right]$ averaged per one centimeter of the profiles changes with the depth and varies at each of the studied objects (Tab. 5).

Table 5. Masses of SOC per centimeter of depth for differentiated layers and dumps $\left[\mathrm{Mg} \cdot \mathrm{ha}^{-1}\right]$

\begin{tabular}{|c|c|c|c|c|c|c||}
\hline \multirow{2}{*}{ Object } & Layer & $\begin{array}{c}N \text { of } \\
\text { valid }\end{array}$ & Mean & Minimum & Maximum & $\begin{array}{c}\text { Standard } \\
\text { deviation }\end{array}$ \\
\hline \hline \multirow{4}{*}{ Bełchatów } & $0-5$ & 45 & 1.536237 & 0.219620 & 5.039949 & 1.046747 \\
\cline { 2 - 7 } & $5-10$ & 44 & 0.732288 & 0.087360 & 5.878346 & 0.957541 \\
\cline { 2 - 7 } & $10-20$ & 41 & 0.277650 & 0.006480 & 1.582841 & 0.294417 \\
\cline { 2 - 7 } & $20-40$ & 35 & 0.120669 & 0.047813 & 0.221976 & 0.075019 \\
\hline \multirow{5}{*}{ Machów } & $0-5$ & 30 & 3.146757 & 1.620000 & 4.389120 & 0.672228 \\
\cline { 2 - 7 } & $5-10$ & 30 & 0.738622 & 0.033250 & 1.610510 & 0.412592 \\
\cline { 2 - 7 } & $10-20$ & 17 & 0.171806 & 0.003743 & 0.510180 & 0.157372 \\
\cline { 2 - 7 } & $20-40$ & 14 & 0.122488 & 0.001271 & 0.351754 & 0.116441 \\
\hline \multirow{5}{*}{ Turów } & $0-5$ & 31 & 2.195252 & 0.564228 & 3.399214 & 0.786027 \\
\cline { 2 - 7 } & $5-10$ & 33 & 0.872872 & 0.140239 & 2.418800 & 0.536640 \\
\cline { 2 - 7 } & $10-20$ & 33 & 0.362118 & 0.000045 & 1.226225 & 0.300292 \\
\cline { 2 - 7 } & $20-40$ & 33 & 0.156316 & 0.000260 & 0.943195 & 0.223583 \\
\hline
\end{tabular}

The first five-centimeter layer with the highest $C$ mass was determined in the grounds of the Machów dump, followed by the Turów dump. The lowest value was measured at the Bełchatów dump (Tab. 5). One can draw the conclusion that time is less important in the process of accumulation than the lithology of the grounds and probably the species differences of the tree stands (Tab. 1, Fig. 1). This is also indicated by the MARSpline model constructed in the same manner as the accumulation of carbon in the profile:

$$
C_{\text {Lay }}=0.227+1.31 \times B F 1+1.61 \times B F 1 \times B F 2+0.55 \times B F 3+0.66 \times B F 1 \times B F 4 ，
$$

where:

$C_{\text {Lay }}-$ mass of organic carbon in soil layer $1 \mathrm{~cm}\left[\mathrm{Mg} \cdot \mathrm{ha}^{-1}\right]$,

$B F 1=1$ for soil layer $0-5 \mathrm{~cm}$ and 0 in other cases,

$B F 2=1$ for object Machów and 0 in other cases,

$B F 3=1$ for soil layer $5-10 \mathrm{~cm}$ and 0 in other cases,

$B F 4=1$ for object Turów and 0 in other cases.

The determination coefficient for the model is $R^{2}=0.67$ (average coefficient in five-fold validation $R^{2}=0.60$ ) 


\subsection{Assessment of Increase in C Resources in Mineral Formations}

The present state of the organic carbon stock in the mine soils represents a very early phase of the soil-formation process.

Table 6. Description statistics of resources of organic carbon for individual objects $\left[\mathrm{Mg} \cdot \mathrm{ha}^{-1}\right]$

\begin{tabular}{||l|c|c|c|c|c|c|c|}
\hline \hline \multicolumn{1}{|c|}{ Object } & No. & Mean & Minimum & Maximum & $\begin{array}{c}\text { Lower } \\
\text { quartile }\end{array}$ & $\begin{array}{c}\text { Lower } \\
\text { quartile }\end{array}$ & $\begin{array}{c}\text { Standard } \\
\text { deviation }\end{array}$ \\
\hline \hline Bełchatów & 45 & 14.06 & 3.12 & 57.45 & 8.46 & 17.34 & 9.99 \\
\hline Machów & 30 & 21.54 & 11.37 & 31.93 & 18.06 & 25.52 & 5.20 \\
\hline Turów & 32 & 21.68 & 9.45 & 36.78 & 18.44 & 24.65 & 6.11 \\
\hline
\end{tabular}

As indicated by the data in Table 6, the objects of Machów and Turów are now characterized by a similar level of $C$ accumulation, significantly higher than the average level in Bełchatów. The variability of the carbon mass per hectare in Bełchatów is much higher than in both of the other objects.

Table 7. Descriptive statistics of mean increases of resources for individual objects $\left[\mathrm{Mg} \cdot \mathrm{ha}^{-1} \cdot\right.$ year $\left.^{-1}\right]$

\begin{tabular}{||l|c|c|c|c|c|c|c|}
\hline \hline \multicolumn{1}{|c|}{ Object } & No. & Mean & Minimum & Maximum & $\begin{array}{c}\text { Lower } \\
\text { quartile }\end{array}$ & $\begin{array}{c}\text { Lower } \\
\text { quartile }\end{array}$ & $\begin{array}{c}\text { Standard } \\
\text { deviation }\end{array}$ \\
\hline \hline Bełchatów & 42 & 0.53 & 0.11 & 1.13 & 0.36 & 0.70 & 0.24 \\
\hline Machów & 30 & 1.09 & 0.52 & 1.60 & 0.87 & 1.25 & 0.28 \\
\hline Turów & 32 & 0.63 & 0.25 & 1.31 & 0.51 & 0.74 & 0.19 \\
\hline
\end{tabular}

There are also visible differences in the rate of the organic carbon stock increase in the studied objects (Tab. 7). These can be the result of the variability of the sites (grounds) or differences in the species composition of the forest stands. The regression obtained by the use of MARSpline algorithm is the expression of the differences observed in the studied case of the three reclaimed objects. The model takes on the following form:

$$
\begin{gathered}
\Delta C=0.778+0.904 \times B F 1-0.0258 \times B F 1 \times B F 2+0.388 \times B F 3-0.0623 \times B F 4- \\
+0.0638 \times B F 2 \times B F 5,
\end{gathered}
$$

where:

$\Delta C$ - average annual increase in pool of organic carbon in 0-30 $\mathrm{cm}$ layer $\left[\mathrm{Mg} \cdot \mathrm{ha}^{-1} \cdot\right.$ year $\left.^{-1}\right]$

$B F 1=1$ for alder-ash stand (Alnus glutinosa + Fraxinus excelsior) and 0 in other cases, $B F 2=\max (0$, Age -11$)$, Age - age of the stand [years],

$B F 3=1$ for ash stand (Fraxinus excelsior) and 0 in other cases,

$B F 4=\max (0,7.384-$ Clitt $)$, Clitt - mass of organic carbon in litter $\left[\mathrm{Mg} \cdot \mathrm{ha}^{-1}\right]$,

$B F 5=1$ for position on slope and 0 in other cases. 
The models allow for distinguishing factors that probably influenced the average increase in the organic carbon mass. Considering the large variability of the phenomenon, the compliance of the model with the observation data $\left(R^{2}=0.64\right.$, average coefficient in five-fold validation $R^{2}=0.59$, Fig. 2) can be regarded as satisfactory. At the same time, one should remember its limitations.

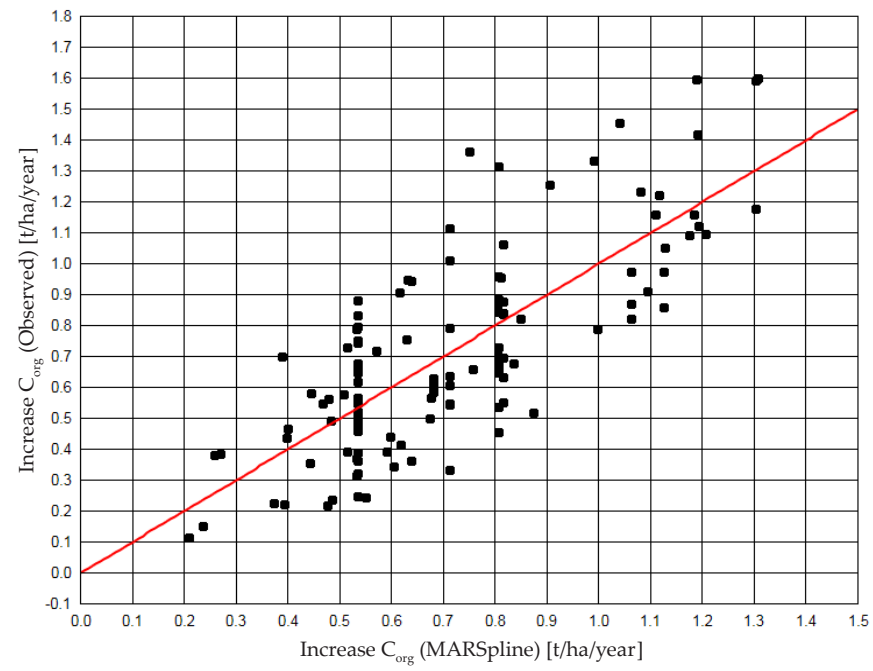

Fig. 2. Plot of $C_{\text {org }}$ stock increase modeled with MARSpline and observed $C_{\text {org }}$ stock increase

Observations of the positive influence that the ash tree stands and ash-alder tree stands had on the rate of the SOC pool increase in the soils are also confirmed by the graph in Figure 3. These observations corroborate the results of the monitoring of forests in Poland [13, 28, 29].

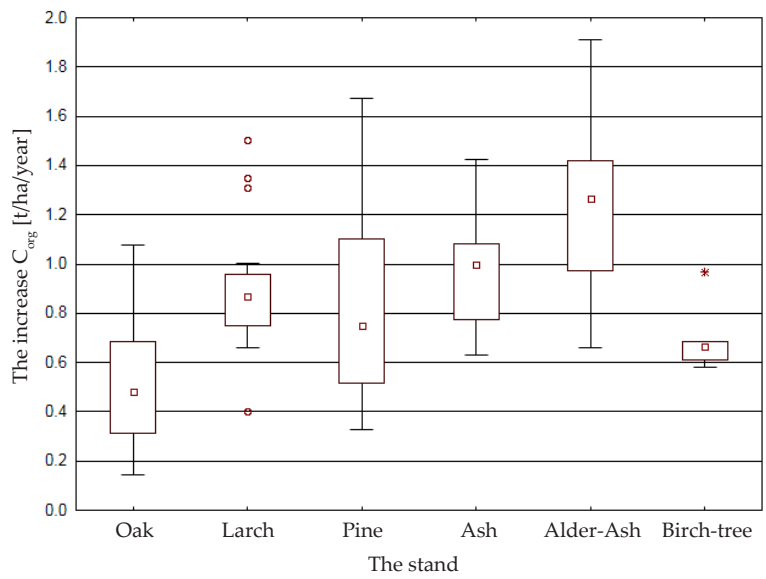

Fig. 3. Annual increase of $C$ in reclaimed grounds for different tree stands 


\section{Sequestration Potential of Reclaimed Grounds}

The present study was only aimed at determining the accumulated carbon in the soils and did not include the $\mathrm{C}$ stored in the plants and soil organisms. In an assessment of the C stocks, the dominant view is that there is a certain level of SOC that will not be exceeded under particular climatic conditions and particular soil properties nor under the constant conditions of plantation and fertilization [3, 27, 29, 30]. In some publications and reports, there is data referring to the resources of organic carbon accumulated in the forest soils of Poland and Germany [29, 31, 32] that could be treated as representative of the moderate climate. The average stock of SOC per ha of the studied tree stands varied between 50 and $114 \mathrm{Mg} \cdot \mathrm{ha}^{-1}$ (depending on the habitat structure). One can assume that the proper reference points for the reclaimed areas can be at SOC levels of about $60 \mathrm{Mg} \cdot \mathrm{ha}^{-1}$ for coarse formations, about $90 \mathrm{Mg} \cdot \mathrm{ha}^{-1}$ for medium formations, and about $110 \mathrm{Mg} \cdot \mathrm{ha}^{-1}$ for more-fertile fine formations. Higher values of SOC accumulation can be related to the formation of humid habitats.

Regarding the carbon stock in the studied objects, one can state that the sequestration potential to the state of stabilization of SOC will be about $40-50 \mathrm{Mg} \cdot \mathrm{ha}^{-1}$ for Bełchatów, 80-90 Mg · ha ${ }^{-1}$ for Machów, and about 60-70 Mg $\cdot$ ha $^{-1}$ for Turów.

The comparison of the sequestration potential with the observed average annual increase of SOC stocks allows us to estimate the time needed to obtain a stabile carbon stock in the soils. For Bełchatów, this period can be estimated as 80-100 years from now; for Machów, this would take 80-90 years, and for Turów, this would take 100-120 years. These times will probably be longer because the accumulation rate will decrease over time $[9,10,12,33,34]$.

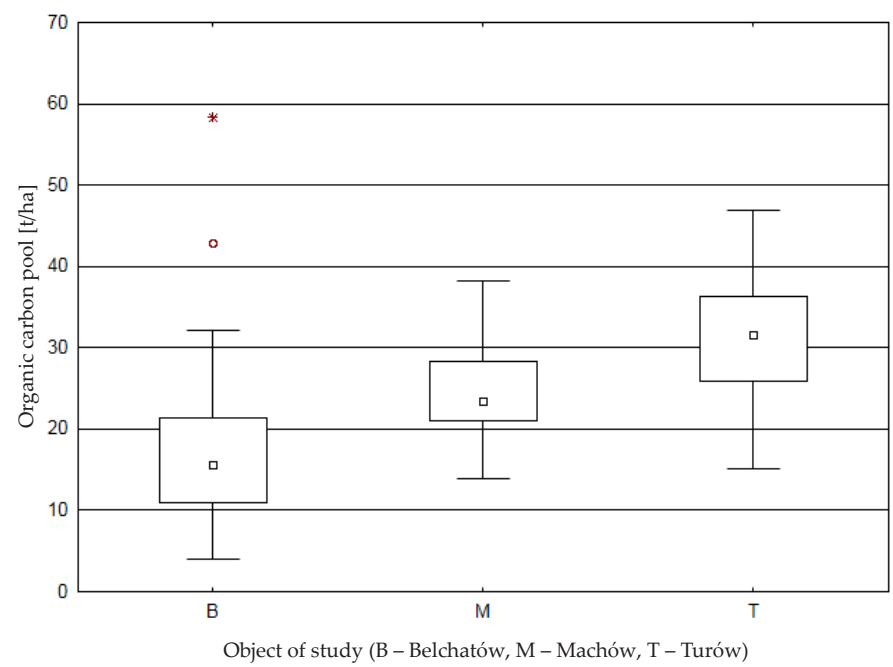

Fig. 4. Comparison of sum of carbon resources in mineral and organic part of soil in subsequent objects 
In the speculations given above, only the carbon stock in the mineral part of the soil was considered. After regarding the carbon contained in the litter (assuming that its part will transform into humus), we obtain some other picture of the carbon stocks in the studied objects (Fig. 4).

Constructed for these values, the general model of MARSpline underlines time as a factor that increases the general resource of carbon in the reclaimed soils as well as the localization of the soil on the shelf or slope of the object and the presence of an ash tree stand:

$$
C_{\mathrm{M}+\mathrm{L}}=12.5+0.32 \times B F 1+13.3 \times B F 2-13.5 \times B F 3+0.97 \times B F 4+0.59 \times B F 5,
$$

where:

$C_{\mathrm{M}+\mathrm{L}}-$ mass of organic carbon in soil to depth of $30 \mathrm{~cm}$ (mineral layer + litter) $\left[\mathrm{Mg} \cdot \mathrm{ha}^{-1}\right]$,

$B F 1=\max (0, A g e-11)$, Age - age of stand [years],

$B F 2=1$ for position on shelf and 0 in other cases,

$B F 3=1$ for oak stand (Quercus robur) and 0 in other cases,

$B F 4=1$ for position on slope and 0 in other cases,

$B F 5=1$ for ash stand (Fraxinus excelsior) and 0 in other cases.

$R^{2}=0.66$, average coefficient in five-fold validation $R^{2}=0.61$.

\section{Conclusions}

Other than fossil resources of carbon, the organic carbon stock accumulated in soils is the highest pool of this element on a global scale. Explaining the mechanisms controlling the organic $C$ content in soils is one of the most important research tasks.

An SOC pool increases until achieving the equilibrium state; this is controlled by the properties of the soil, types of vegetation, climatic conditions, and fertilization. The most widely applied method in the modeling of the SOC stock formation is the RothC model of the turnover of soil carbon [35]. This includes five components characterized by a certain susceptibility to decomposition, which is affected by the meteorological conditions and soil organisms. The estimation of the components in soil with a stable SOC stock only requires knowledge about the summary SOC pool and the proportion of plant contribution in the subsequent months. This solution works well under stabile soil conditions.

Assuming the conditions of an equilibrium SOC pool to be $110 \mathrm{Mg} \cdot \mathrm{ha}^{-1}$, the estimation of the present carbon stock in the studied dumps with the RothC model does not yield results supported by the carried-out observations. There are large differences in both the determined and estimated mean amounts of SOC and in the proportions of the subsequent components. This leads to the conclusion that the 
use of the model developed for mature habitats does not allow for a reliable estimation of the SOC accumulation in the initial phase of the soil-forming processes.

Obtained based on the carried-out research, the MARSpline models showed that the strongest influence on carbon sequestration during forest reclamation of soilless formations has their lithology (texture), the time is less important. Certain importance can also be attributed to the localization on the slope or on the horizontal surface as well as the species composition, as the carbon accumulation is relatively higher in the ash-alder and ash stands. These tree stands should be preferred on reclaimed objects, at least in the initial phase of reclamation and particularly when the purpose is to maximize the accumulation of carbon in the reclaimed soils.

Obtaining stable SOC levels at all of the studied objects will last for a long time (no less than 80-120 years). Until that time, the potential of $\mathrm{CO}_{2}$ sequestration by these reclaimed mine soils can be from 2.2 to about $3.6 \mathrm{Mg} \cdot \mathrm{ha}^{-1} \cdot$ year $^{-1}$. This relatively small amount has a different scale due to the large surfaces covered by dumps in the majority of reclamations for forest management in Poland.

\section{References}

[1] Carbon sequestration in agricultural soils. Economic and Sector Work. Report No. 67395.GLB. The World Bank, 2012.

[2] Lal R.: Carbon management in agricultural soils. Mitigation and Adaptation Strategies for Global Change, vol. 12, 2007, pp. 303-322.

[3] Sundquist E.T., Ackerman K.V., Bliss N.B., Kellndorfer J.M., Reeves M.C., Rollins M.G.: Rapid assessment of U.S. forest and soil organic carbon storage and forest biomass carbon sequestration capacity. U.S. Geological Survey OpenFile Report 2009-1283, p. 15, [on-line:] http://pubs.usgs.gov/ofr/2009/1283 [access: 10.05.2017].

[4] Directive 2009/28/EC of the European Parliament and of the Council on the promotion of the use of energy from renewable sources and amending and subsequently repealing Directives 2001/77/EC and 2003/30/EC., 23 April 2009. Official Journal of the European Union L 140, 5 June 2009.

[5] Garcia-Oliva F., Masera O.R.: Assessment and Measurement Issues related to soil carbon sequestration in land-use, land-use change, and forestry (luluce) projects under the Kyoto protocol. Climatic Change, vol. 65, 2004, pp. 347-364.

[6] Falloon P.D., Smith P., Smith J.U., Szabó J., Coleman K., Marshall S.: Regional estimates of carbon sequestration potential: linking the Rothamsted Carbon Model to GIS databases. Biology and Fertility of Soils, vol. 27, 1998, pp. 236-241.

[7] Gillis J.D., Price G.W.: Comparison of a novel model to three conventional models describing carbon mineralization from soil amended with organic residues. Geoderma, vol. 160, 2011, pp. 304-310. 
[8] Heikkkinen J., Kurganova I., de Gerenyu V.L., Palosuo T., Regina K.: Changes in soil carbon stock after cropland conversion to grassland in Russian temperate zone: measurement versus model simulation. Nutrient Cycling in Agroecosystems, vol. 98, 2014, pp. 97-106.

[9] Akala V.A., Lal R.: Potential of mine land reclamation for soil organic carbon sequestration in Ohio. Land Degradation \& Development, vol. 11, issue 3, 2000, pp. 289-297.

[10] Gołda T.: Inicjalne procesy glebotwórcze zachodzace w szlamach poflotacyjnych w wyniku upraw rekultywacyjnych $i$ wieloletniego użytkowania rolnego. Rozprawy i Monografie, 164, Uczelniane Wydwanictwa Naukowo-Dydaktyczne AGH, Kraków 2007.

[11] Kowalik S.: Właściwości chemiczne gleb industrioziemnych użytkowanych rolniczo i leśnie na zrekultywowanym zwałowisku kopalni siarki "Machów". Roczniki Gleboznawcze, t. 55, nr 2, 2004, pp. 239-249.

[12] Pietrzykowski M., Krzaklewski W.: Soil organic matter, $C$ and N accumulation during natural succession and reclamation in an opencast sand quarry (southern Poland). Archives of Agronomy and Soil Science, vol. 53, 2007, pp. 473-483.

[13] Wójcik J., Krzaklewski W.: Akumulacja materii organicznej w inicjalnych glebach na zwałowisku zewnętrznym Kopalni Węla Brunatnego "Adamów". Roczniki Gleboznawcze, t. 58, nr 3/4, 2007, pp. 151-158.

[14] Jekabsons, G.: ARESLab: Adaptive Regression Splines toolbox for Matlab/ Octave. [on-line:] http://www.cs.rtu.lv/jekabsons [access: 10.05.2017].

[15] Grabowska-Olszewska B.: 1968: Bentonit i grunty ilaste z Machowa. Biuletyn Geologiczny - Uniwersytet Warszawski. Wydział Geologii, r. 10, 1968, pp. 5-104.

[16] Rybicki S., Kaczmarczyk R., Borecka A.: Właściwości gruntu zwałowego z KWB Turów. Górnictwo Odkrywkowe, nr 4-5, 1999, pp. 132-148.

[17] Stoch L., Helios-Rybicka E.: Charakterystyka mineralogiczna iłów nadkładowych złoża siarki w Jeziórku. Kwartalnik Geologiczny, t. 17, nr 1, 1973, pp. 106-117.

[18] Wojtanowicz P.: Ocena potencjalnego zakwaszenia utworów nadkładu i zwałowisk KWB Betchatów dla potrzeb rekultywacji. Archiwum IKOŚ AGH, Kraków 2000 [Ph.D. Thesis, manuscript].

[19] Bykov R.: Litologiczne i morfologiczne uwarunkowania procesów glebowych na terenie zrekultywowanego zwałowiska zewnętrznego kopalni siarki "Piaseczno". Archiwum WGGiIŚ AGH, Kraków 2003 [Ph.D. Thesis, manuscript].

[20] Bykov R., Eckes T., Trafas M.: Quality Assessment of Reclaimed Areas of Strip Mines by Example of Piaseczno Mine Dump. Geomatics and Environmental Engineering, vol. 4, no. 2, 2010, pp. 33-53.

[21] Carter M.R., Gregorich E.G., Angers D.A., Donald R.G., Bolinder M.A.: Organic $C$ and $N$ storage, and organic $C$ fractions, in adjacent cultivated and forested soils of eastern Canada. Soil \& Tillage Research, vol. 47, 1998, pp. 253-261. 
[22] Gołda T., Gruszczyński S.: Zmiany niektórych właściwości szlamów poflotacyjnych pod wptywem upraw rekultywacyjnych. Zeszyty Naukowe AGH, nr 1452, Sozologia i Sozotechnika, 36, Państwowe Wydawnictwo Naukowe, Warszawa - Kraków 1991.

[23] Węgorek T.: Zmiany niektórych właściwości materiału ziemnego i rozwój fitocenoz na zwałowisku zewnętrznym kopalni siarki w wyniku leśnej rekultywacji docelowej. Rozprawy Naukowe Akademii Rolniczej w Lublinie. Wydział Rolniczy, z. 275, Wydawnictwo Akademii Rolniczej, Lublin 2003.

[24] Wójcik J., Krzaklewski W.: Kształtowanie się cech inicjalnej gleby w toku leśnej rekultywacji zwałowiska zewnętrznego KWB „Adamów”. [in:] Górnictwo odkrywkowe - środowisko - rekultywacja, ze szczególnym uwzględnieniem KWB “Betchatów": międzynarodowa konferencja naukowa. Roślinność spontaniczna jako wskaźnik warunków siedliskowych oraz podstawa do zalesiania skarp zwałowisk na przykładzie Kopalni Wegla Brunatnego "Adamów", Kraków 1999, p. 95-109.

[25] Charles T., Garten Jr.: A disconnect between O horizon and mineral soil carbonImplications for soil C sequestration. Acta Oecologica, vol. 35, 2009, pp. 218-226.

[26] Lal R.: Agricultural activities and the global carbon cycle. Nutrient Cycling in Agroecosystems, vol. 70, 2004, pp. 103-116.

[27] Lal R.: Forest soils and carbon sequestration. Forest Ecology and Management, vol. 220, 2005, pp. 242-258.

[28] Brożek S., Zwydak M., Lasota J.: Gleby borów sosnowych świeżych Leucobryo-Pinetum i Peucedano-Pinetum na obszarze niżu Polski. Roczniki Gleboznawcze, t. 58, nr 3/4, 2007, pp. 43-51.

[29] Wójcik J.: Możliwości zwiększania sekwestracji węgla w ekosystemach leśnych w warunkach zmian klimatycznych. Gromadzenie wegla w glebie, ochrona materii organicznej. [in:] Rykowski K. (red.), Klimat: lasy i drewno a zmiany klimatyczne: zagrożenia i szanse: materiaty pierwszego panelu ekspertów w ramach prac nad Narodowym Programem Leśnym, Sękocin Stary, 18 czerwca 2013 roku, Instytut Badawczy Leśnictwa, Sękocin Stary 2014, pp. 156-173.

[30] Gottschalk P., Smith J.U., Wattenbach M., Bellarby J., Stehfest E., Arnell N., Osborn T.J., Jones C., Smith P.: How will organic carbon stocks in mineral soils evolve under future climate? Global projections using RothC for a range of climate change scenarios. Biogeosciences, vol. 9, 2012, pp. 3151-3171.

[31] Małachowska et al.: Monitoring lasów: ocena stanu zdrowotnego lasów w latach 1991 - 2005. Biblioteka Monitoringu Środowiska, GIOŚ, Warszawa 2007.

[32] Wiesmeier M., Prietzel J., Barthold F., Spörlein P., Geuß U., Hangen E., Reischl A., Schilling B., von Lützow M., Kögel-Knabner I.: Storage and drivers of organic carbon in forest soils of southeast Germany -Implications for carbon sequestration. Forest Ecology and Management, vol. 295, 2013, pp. 162-172.

[33] Delschen T.: Impacts of long-term application of organic fertilisers on soil quality parameters in reclaimed loess soil of the Rhineland lignite mining area. Plant and Soil, vol. 213, 1999, pp. 43-54. 
[34] Ingram J.S.I., Fernandes E.C.M.: Managing carbon sequestration in soils: concepts and terminology. Agriculture, Ecosystems and Environment, vol. 87, 2001, pp. 111-117.

[35] Coleman K., Jenkinson D.S.: RothC-26.3. A model for turnover of carbon in soil. Model description and windows users guide. Rothamsted Research Harpenden Herts AL5 2JQ, November 1999 issue (modified August 2008).

\section{Przyrost puli węgla organicznego w glebach we wczesnej fazie leśnego zagospodarowania nieużytków pogórniczych}

Streszczenie: Praca zawiera wyniki badań zawartości węgla organicznego w inicjalnych glebach powstających z utworów bezglebowych rekultywowanych w celu ich leśnego zagospodarowania. Uzyskane dane pozwoliły na określenie zasobów węgla w warstwie organicznej i przypowierzchniowych poziomach mineralnych, a także na zbudowanie modeli umożliwiających wytypowanie głównych czynników wpływających na tempo jego przyrostu. Najsilniejszy wpływ na sekwestrację węgla w trakcie leśnej rekultywacji utworów bezglebowych ma ich litologia (uziarnienie), skład gatunkowy wprowadzonych nasadzeń (korzystniejsze drzewostany jesionowo-olchowe i olchowe), mniejsze znaczenie ma wpływ czasu, usytuowanie na skłonie czy powierzchni poziomej. Obliczone roczne przyrosty węgla wskazuja, że okres potrzebny do nagromadzenia węgla w glebach rekultywowanych, w ilości zbliżonej do zasobów w naturalnych glebach leśnych, wynosi ponad 100 lat.

Słowa

kluczowe: rekultywacja, tereny bezglebowe, sekwestracja $\mathrm{C}$, obrót węglem glebowych 